\title{
Lavinia Fontana’s Galatea: Personification of Fortune and
}

\section{Venus}

\author{
Liana De Girolami Cheney \\ SIELAE, Universidad de Coruña, Spain
}

\begin{abstract}
Lavinia Fontana’s (1552-1614) Galatea and Cherubs riding the Stormy Waves on a Sea Monster (aka Galatea) of 1590 is an intriguing mythological painting. Being painted on copper, it is a fine example of Lavinia's exploration of new artistic techniques and materials as well as testimony to her bold artistic interpretations. Lavinia's Galatea was part of a private collection in Bologna (Diletta Badeschi). This work fascinates the viewer with its erotic audacity and complex iconographical conceits. Recent scholarship by Daniele Benati, Fausto Gozzi, and Enrico Maria Dal Pozzolo assist in unraveling the meaning of this painting. In this essay there are additional interpretative suggestions.
\end{abstract}

Keywords: mannerism, emblems, engravings, mythology, sea monsters, symbolism, Lavinia Fontana, Marcantonio Raimondi, Achille Bocchi, Andrea Alciato, Vincenzo Cartari, Galatea, Fortune, Venus

\section{Lavinia Fontana’s Galatea}

Lavinia Fontana's (1552-1614) Galatea and Cherubs riding the Stormy Waves on a Sea Monster (aka Galatea) of 1590 (Figure 1) is an intriguing mythological painting. Being painted on copper, it is a fine example of Lavinia's exploration of new artistic techniques and materials as well as testimony to her bold artistic interpretations. ${ }^{1}$

Lavinia as an artist not only studied the depiction of new subject matters in secular paintings but also experimented with artistic techniques and materials such as painting on copper (rame). ${ }^{2}$ Some of her small secular paintings such as Galatea and Venus Receiving a Tribute from Amorini of 1610 (private collection in Bologna) are done in copper, which provided them with new visual quality and durability. This surface technique for painting, known in antiquity, became popular in the Italian Renaissance with Leonardo da Vinci. ${ }^{3}$

Liana De Girolami Cheney, Ph.D. Visiting Scholar in Art History SIELAE, University of Coruña, Spain.

Acknowledgements: I want to express my gratitude to Profs. Vera Fortunati, Fausto Gozzi, and Enrico Maria Dal Pozzolo, and Dr. Laura Falqui of Bologna for their assistance and comments.

${ }^{1}$ N.B. In this essay I have referred to Lavinia Fontana by her first name in order not to be confused with her father Prospero Fontana.

2 See Michael Komanecky, ed., Copper as Canvas: Two Centuries of Masterpiece Painting on Copper, 1575-1775 (Phoenix, AZ: Phoenix Art Museum, exh. 1998-1999), Introduction, 70; and Andrew Hemming, "The New Technique of Painting on Copper," in Martin Roth et al., Capture Emotions: Baroque Paintings in Bologna 1575-1725 (Los Angeles, CA: J. Paul Getty, 2008), 25-37, esp. 25-26.

3 Komanecky, Copper as Canvas, Introduction. 


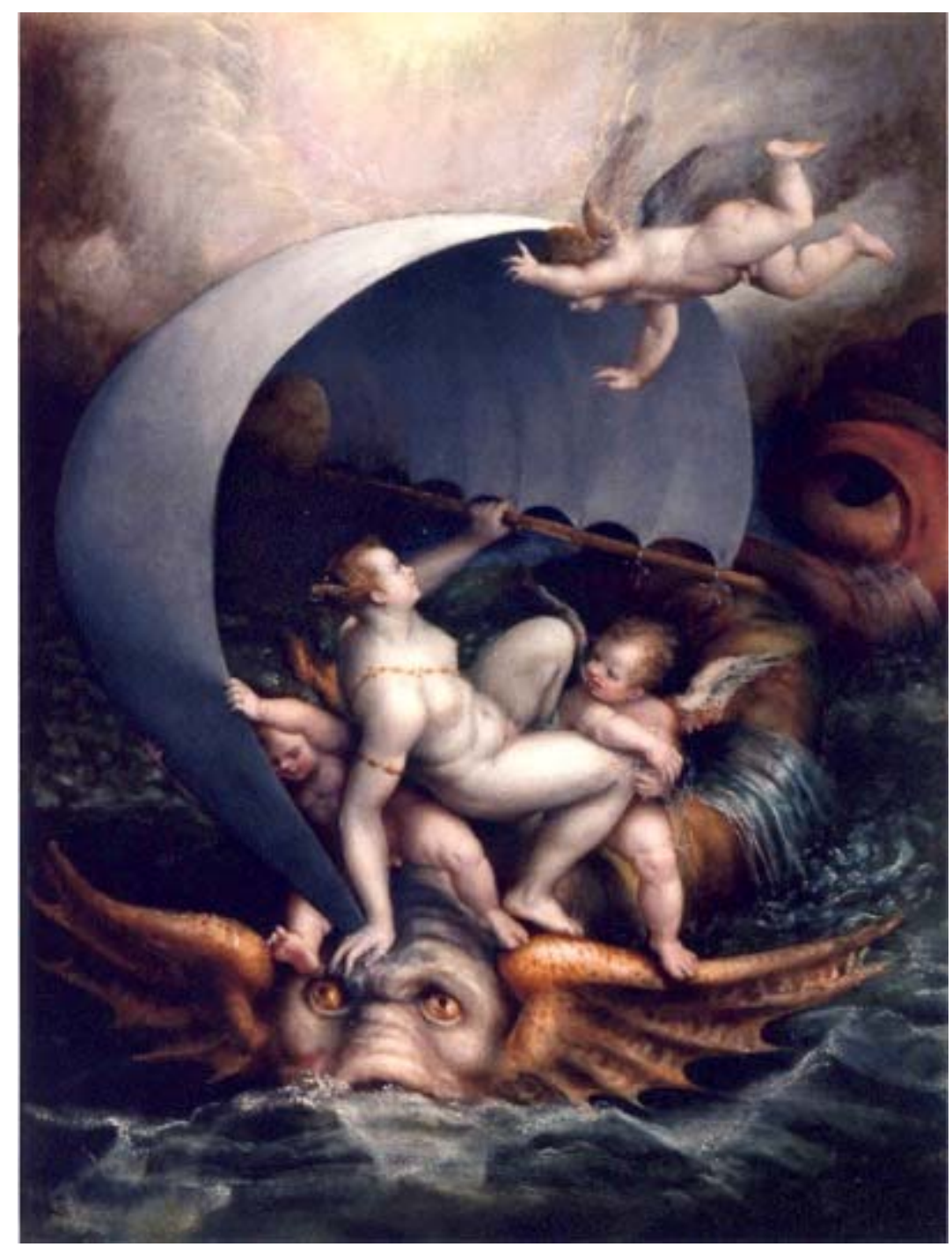

Figure 1. Lavinia Fontana, Galatea, 1590. Private collection in Bologna. Diletta Badescki.

Photo credit: Courtesy of Prof. Fausto Gozzi and Mauro Lizzi, Editor, Zel.Edizioni.

The metal was used as canvas for two reasons: surface smoothness and durability as well the rich color effects achieved with the application of colors. Treating the surface of the copper with garlic or white lead paint facilitated the adherence of oil paint to the plate. This type of coating provided reflective surfaces and transparencies like crystal effects. Another significant factor was the employment of natural stones such as azurite, malachite, and verdigris for the production of the colors blue, green, and bluish green in paintings. This application was particularly used for depictions of landscapes and jewelry decoration. In using copper as canvas and natural stones, Lavinia obtained a smooth surface and rich color effects as seen in Galatea, notably in the treatment of the seascape with its brilliance of coloration and silvery reflection, thereby preserving the painting for posterity. ${ }^{4}$

\footnotetext{
${ }^{4}$ See Sheila Barker, “Exhibition Review: ‘A Tale of Two Women Painters,”’ Burlington Magazine (2020), where Lavinia’s Galatea is referred to as "an exquisitely finished copper” painting.

See https://www.academia.edu/41653667/Exhibition_Review_A_Tale_of_Two_Women_Painters (accessed January 15, 2020).
} 
Lavinia's Galatea was part of a private collection in Bologna (Diletta Badeschi). This work fascinates the viewer with its erotic audacity and complex iconographical conceits. Recent scholarship by Daniele Benati, Fausto Gozzi, and Enrico Maria Dal Pozzolo assist in unraveling the meaning of this painting. ${ }^{5}$

In this painting, Lavinia continued her interpretation of the classical myth narrated in Ovid's Metamorphoses (Book 13:705-870) of Polyphemus's unrequited love for the beautiful Galatea. His love song chants:

Galatea, whiter than the snowy privet petals, taller than slim alder, more flowery than the meadows, friskier than a tender kid, more radiant than crystal, smoother than shells, polished, by the endless tides; more welcome than the summer shade, or the sun in winter, showier than the tall plane-tree, fleeter than the hind; more than ice sparkling, sweeter than grapes ripening, softer than the swan's-down, or the milk when curdled, lovelier, if you did not flee, than a watered garden. Galatea, likewise, wilder than an untamed heifer, harder than an ancient oak, trickier than the sea; tougher than the willow-twigs, or the white vine branches, firmer than these cliffs, more turbulent than a river, vainer than the vaunted peacock, fiercer than the fire; more truculent than a pregnant bear, pricklier than thistles, deafer than the waters, crueler than a trodden snake; and, what I wish I could alter in you, most of all, is this: that you are swifter than the deer, driven by loud barking, swifter even than the winds, and the passing breeze. ${ }^{6}$

Galatea was the daughter of Nereus, a Nereid, and Doris, an Oceanid. The Nereids, whose name means "flowing, liquid" in Greek, were water nymphs who lived in the sea, typically riding on sea creatures, dolphins, tritons, or sea monsters - throughout the many pools of water. To distinguish her from her sister Nereids and also because of the light color of her skin, she was called Galatea, meaning "white-sea-foam" or "she who is milk white" in Greek. She loved another sea creature, the handsome and young river demi-god Acis, son of Pan and the nymph Symaethis. Galatea's romantic activities provoked the wrath of the ugly cyclops Polyphemus, who pined for her affection. After seducing Polyphemus, flirtatious Galatea switched her amorous interests toward the handsome and young Acis. In an act of jealous rage when seeing the couple together at sea, Polyphemus hurled a giant rock at Acis and killed him in a "wrath more powerful than the lightening flash of Jupiter" (Ovid, Meta. 13.854). In witnessing this violent act, Galatea was "amazed with horror [and] plunged into the sea” (Ovid, Meta. 13.870).

\footnotetext{
${ }^{5}$ Daniele Benati, “Un quadro grande con donne nude: da Joachim Wtewael a Lorenzo Sabatini,” in Daniele Benati, ed., Il più dolce lavorare che sia: mélanges en l’honneur de Mauro Natale (Ciniselo, Balsamon (Milan): Silvana, 2009), 115-21l, Lavinia’s painting originally in a private collection in Bergamo; Fausto Gozzi, "Catalogue and Cherubs riding the Stormy Waves on a Sea Monster,” cat. entry, in Leticia Ruiz Gómez, ed., A Tale of Two Women Painters: Sofonisba Anguissola and Lavinia Fontana (Madrid: MuseoNacional del Prado, 2019), 214 [cited hereafter as Gozzi, "Lavinia’s Galatea”]; and Enrico Maria Dal Pozzolo, Un apice erotico di Lavinia Fontana (Treviso: ZeL Edizioni, 2019), 45-70.

${ }^{6}$ Ovid, Metamorphoses, Book 13:789-869, for the Song of Polyphemus. See Charles Martin, trans. Metamorphoses: New Translation (New York: W. W. Norton \& Company, 2005).
} 
In the painting, Lavinia depicted a swirling composition with concentric circular movements to visualize Ovid's text describing how "with horror [she] plunged into the sea." Riding on the back of a sea monster that moves cautiously through tempestuous ocean waves to save its precious cargo, Galatea holds onto her veil, which functions as a wind-blown sail. Three companions, amorini (putti), ${ }^{7}$ assist her in keeping her balance in the turbulent seas. In the background of the painting there is a powerful heavenly cyclone with smoky colors of white and pinks sent by Jupiter (Zeus, the God of the Sky) to support his brother Neptune (Poseidon, the God of the Sea and father of Polyphemus), who had whipped up the ocean storm in support of his son's wrath. These gods were also attempting to punish the capricious and flirtatious Galatea by drowning. Lavinia visualized the Ovidian text but also included Jupiter's intervention, paralleling his action with the ire of his brother (Neptune) and the wrath of his nephew (Polyphemus).

In her conception of this classical saga, Lavinia was inspired by sixteenth-century Italian emblematic and mythographic traditions that represented the navigation of Galatea, in particular by the published editions of Andrea Alciato's Emblemata (1531), ${ }^{8}$ Vincenzo Cartari’s Imagini delli dei de gl'antichi (1556), ${ }^{9}$ and Achille Bocchi's Symbolicae quaestiones (1555). ${ }^{10}$ In Lavinia’s painting, the overall whirling around and circularity of the design metaphorically suggests the rotation of the Roman Goddess Fortuna's mechanical wheel (rota fortunae) or sphere. ${ }^{11}$ Fortuna, whose name derives from the Latin fero, meaning "to bring or receive [destiny]," was the daughter of the Titans Oceanus and Tethys, gods of Water. Her dual nature of negative and positive forces made Fortuna the goddess of Fate, both good or ill, and the goddess of Luck, again both good or bad. In Andrea Alciato's Emblemata, for example, Fortune (Fortuna) or Opportunity (Occasio) is depicted navigating in a tempestuous ocean on a wheel and carrying a wind-blown veil, which functions as a sail (Figure 2). ${ }^{12}$ Similarly, Lavinia's Galatea grasps a wind-blown sail to steady her navigation. ${ }^{13}$ Lavinia was further inspired by the mythographer Vincenzo Cartari's Galatea in the Imagini delli dei de gl'antichi, where she is navigating in the

\footnotetext{
${ }^{7}$ In recent literature, amorini or putti have been identified as cherubs; since this is a mythological painting the term is confusing. Cherubs is an artistic term used to identify an angelic winged child in religious art, see James Hall, Dictionary of Subjects and Symbols in Art (New York: Harper \& Row, Publishers, 1974, repr. 2014), 16-17; and Alice Wood, Of Wing and Wheels: A Synthetic Study of the Biblical Cherubim (Berlin: Walter de Gruyter, 2008), 2-4.

${ }^{8}$ Lavinia was aware of the emblematic works of Andrea Alciato (1492-1550). This Milanese scholar had studied canon law, humanities, and classics (Greek and Latin) in Milan, Pavia, and Bologna (1511-1514). He had also been a professor of humanistic jurisprudence and philology at the University of Bologna between 1537 and 1541. See Emilio Costa, Andrea Alciato allo studio di Bologna (Bologna: Nicola Zanichelli, 1903), 28; and Peter M. Daly, ed. Andrea Alciato and the Emblem Tradition. Essays in Honor of Virginia Woods Callahan (New York: AMS Press, 1989).

${ }^{9}$ Vincenzo Cartari (1531-1569) was an Italian humanist, mythographer, and diplomat in the court of Ferrara. His iconographical and mythological book Imagini delli dei de gl'antichi was first published in Venice in 1556 and then again in Venice in 1571. This popularized and expanded version included woodcuts by Bolognino Zaltieri. This text became an influential visual manual and mythographic source for artists and humanists in the sixteenth century and beyond. See Jean Seznec, Survival of the Pagan Gods (Princeton, NJ: Princeton University Press, 1972).

${ }^{10}$ Achille Bocchi (1488-1562) was a Bolognese emblematist, historian, and classicist at the University of Bologna. His emblem book Symbolicarum quaestionum (1555/1574) incorporated conceits from his friend Giovanni Pierio Valeriano's Hieroglyphica (Basel: Michael Isengrin, 1556). Bocchi was a close friend of the Fontana family. See John Manning, The Emblem (Edinburg: Reaktion Books, 2002).

11 See David M. Robinson, “The Wheel of Fortune,” Classical Philology 41.4 (October 1946): 207-16.

12 See Andrea Alciato, Emblem In Occasionem or La Occasion (Opportunity or Fortuna), in Los Emblemas (Lyons: Macé Bonhomme for Guillaume Rouille, 1549).

For image and text, see http://www.emblems.arts.gla.ac.uk/alciato/emblem.php?id=A49a016 (accessed December 15, 2019).

13 See note 8.
} 
nude on a propelled scalloped shell, ${ }^{14}$ holding a wind-blown veil to guide her through the sea (see Figure 3). In this engraving, the standing figure of Galatea is flanked by two circles narrating sections of the saga, like small vignettes illustrating her travels on sea creatures accompanied by amorini, as seen in Lavinia's painting of Galatea.

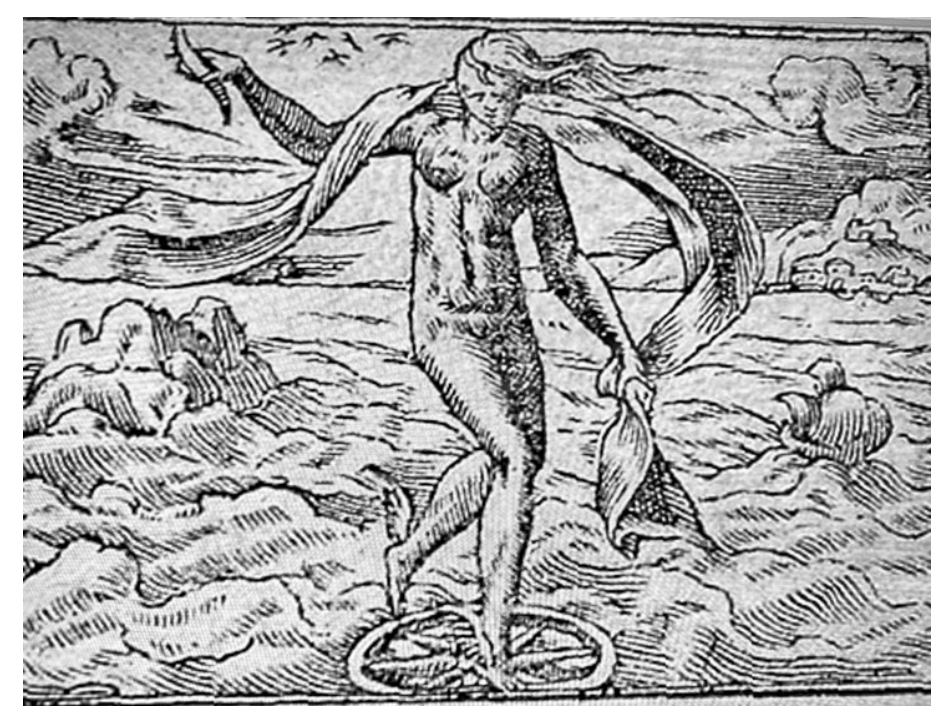

Figure 2. Andrea Alciato, Emblem La Occasion, in Los emblemas (Lyons: Macé Bonhomme for Guillaume Rouille, 1549).

Photo credit: Courtesy of the University of Glasgow Library, Archives \& Special Collections.

The paragone between Galatea and Fortuna alludes to their association of having to navigate through tempestuous storms and to deal with the vicissitudes of fate. Lavinia composed Galatea as an impersonation of Fortuna by painting the events in the scene alluding to Fortuna's interference or protection. The visualization in the painting is constructed in two ways: physically, by showing Galatea's control of the sea navigation amidst tempestuous forces of nature (wind and water); and metaphysically, by the mutability of destiny. In the case of this saga, for example, the killing of Acis by Polyphemus led Galatea to transform Acis's blood into a river, which is hinted at in the painting by red tints shown in the water and around the sea monster's face and tail. In addition, the transformation of the long curving tail of the sea monster into a large eye is not accidental. Lavinia has metaphorically painted the single eye of the cyclops Polyphemus, alluding to his maleficent presence and ability to cause havoc at sea.

\footnotetext{
14 Vincenzo Cartari, Le imagini degli dei degli antichi (Venice: Francesco Marcolini, 1556). An illustrated edition by Bolognino Zaltieri [active 1555-1576] was published in Venice in 1571. For the description of the content, see https://archive.org/stream/imaginidellideid01cart/imaginidellideid01cart\#page/131/mode/1up; and for the image, see https://commons.wikimedia.org/wiki/File:Imagini_delli_dei_de_gl\%27antichi_(1647)_(14746657085).jpg (accessed December 15, 2019).
} 


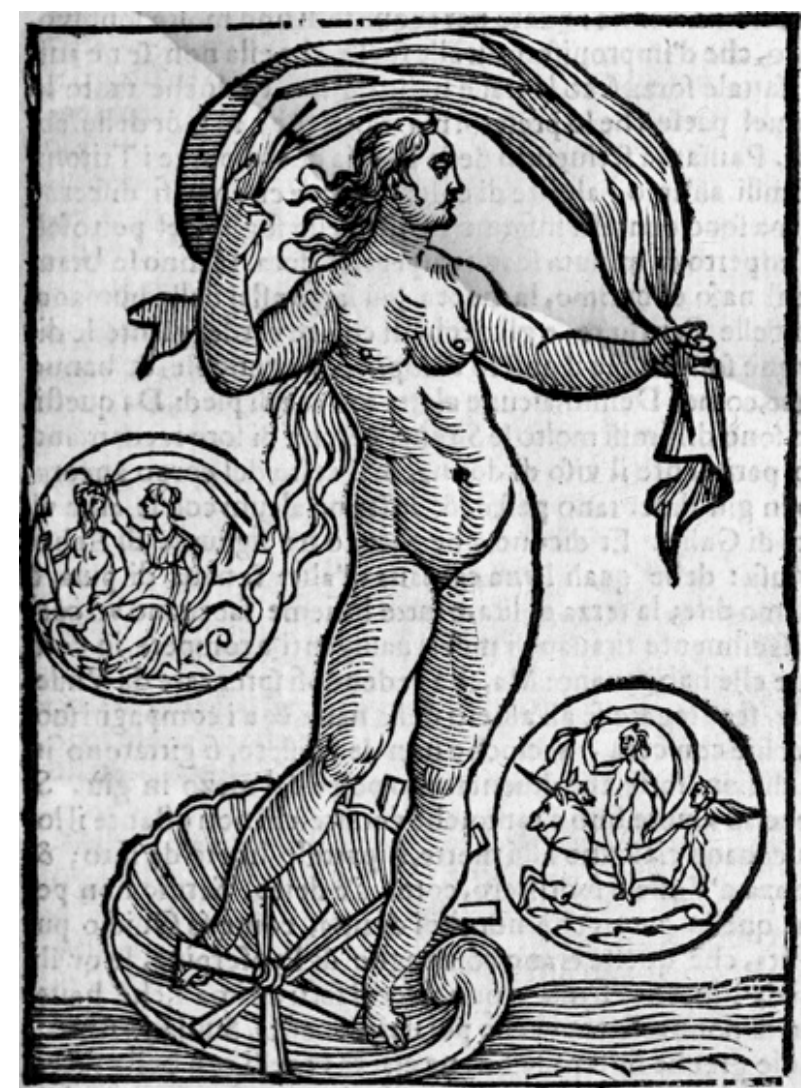

Figure 3. Vincenzo Cartari, Galatea, in Le imagini degli dei degli antichi (Venice: Francesco Marcolini, 1556, rep. 1647).

Photo credit: Commons.wikimedia.org.

Humorously, Lavinia transformed the sea monster's ears into large dragon wings or propelling oars, contrasting with the small, soft, and angelic wings of the amorini. The sea creature's wide-open eyes suggest the difficulty of his struggle to quickly transit the rough ocean waters as well as his fear of the gods' anger; but they also express the tiresomeness of carrying such a heavy cargo. In addition, the sea monster has visibility issues: one of the amorino's feet is pressing against one of his eyebrows, making it difficult to see ahead, while one of Galatea's hands is pushing against his forehead, straining his visual acuity and physical maneuvering. In the selection of this type of sea monster, once again, Lavinia demonstrated her familiarity with Alciato's emblems, for example, in the treatment of the large sea monster-open mouth, flappy pectoral fin, and twisted tail-Lavinia likely drew on a similar image in Alciato’s Emblem CLVII, “On one who perished through the savagery of his own people (In eum, qui truculentia suorum perierit).” Alciato derived the text from his translation of epigrams in the Greek Anthology (Anthologia graeca) (7:216). ${ }^{15}$ "I am a dolphin whom the tide drove ashore against my will, an example showing what great dangers there are in the treacherous sea. For if Neptune does not spare even his own nurslings, who can think that men are safe in ships?” (Figure 4) ${ }^{16}$ Lavinia also drew inspiration from the

\footnotetext{
15 See Peter Jay, ed. The Greek Anthology and Other Ancient Epigrams (Philadelphia, PA: Allen Lane, 1973, rep. Penguin Classics, 1981).

${ }^{16}$ See Andrea Alciato's Emblemata (Padua: Petro Paulo Tozzi, 1621). The emblem was published previously in the first edition of Andrea Alciato's Emblematum liber (Augsburg: Heinrich Steyner, 1531).

For the image, see https://www.emblems.arts.gla.ac.uk/alciato/emblem.php?id=A21a167 (accessed December 15, 2019).
} 
Bolognese culture and its cabinets of curiosities for the study of natural history, in particular with Ulisse Aldrovandi's collection of rare botanical, geological, and zoological specimens. ${ }^{17}$

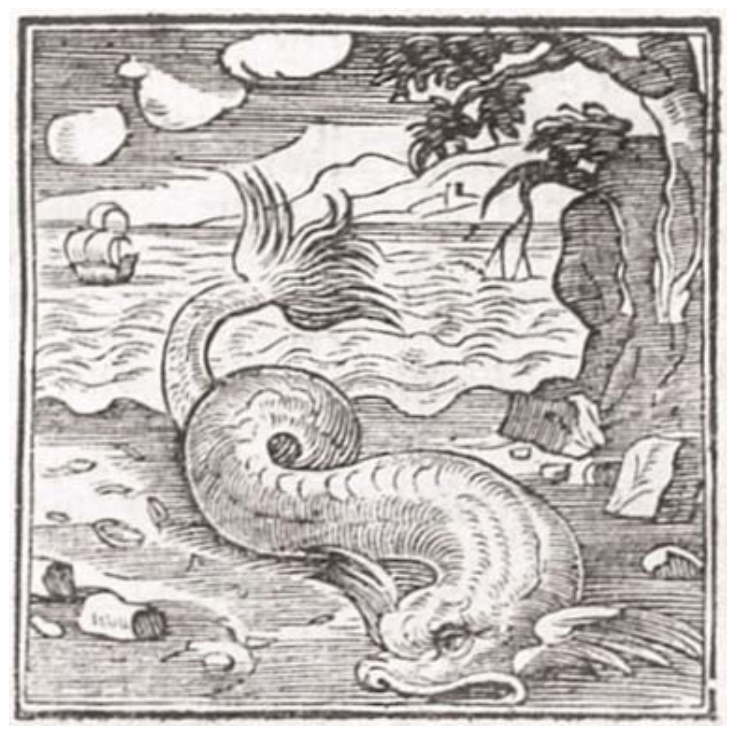

Figure 4. Andrea Alciato, Emblem Emblem CLVII, “On one who perished through the savagery of his own people,” in

Emblemata. (Padua: Petro Paolo Tozzi, 1621, repr. from first edition 1531).

Photo credit: Courtesy of the University of Glasgow Library, Archives \& Special Collections.

Two of the amorini are engaged in helping Galatea control the wind-blown sail amidst the stormy sea. The third amorino, who sits in front of Galatea and rests his arm and body next to her right leg, is oblivious to this task of rescuing her from the storm; he is absorbed in looking at her veiled pudendum. Perhaps his gaze is a reference to Galatea's sexual transgressions. In ancient Roman frescoes, for example, there are images of Galatea's sexual indiscretion in seducing Polyphemus. ${ }^{18}$ In the House of the Ancient Hunt at Pompeii, the couple is depicted in the act of lovemaking (Figure 5). The two appear in a landscape, standing up: the large figure of Polyphemus, with his darker skin coloration, and the semi-nude figure of Galatea, with her light skin coloration, are locked in a passionate embrace. Held in the arms of Polyphemus, Galatea is seen from behind, exposing her buttocks, while sensuously kissing him. He touches her buttocks in a way similar to the scene in Lavinia's Mars and Venus of 1595 in the Fundación Casa de Alba in Madrid. ${ }^{19}$

\footnotetext{
17 See Gozzi, “Lavinia’s Galatea," 214; Marco Ruffini, “A Dragon for the Pope: Politics and Emblematics at the Court of Gregory XIII,” Memories of the American Academy in Rome 54 (2009): 83-105; and Giuseppe Olmi and Paolo Prodi, “Gabriele Paelotti, Ulisse Aldrovandi, e la cultura a Bologna nel secondo Cinquecento,” in Nell'Eta di Correggio e dei Carracci: Pittura in Emilia dei Secoli XVI e XVII (Bologna: Nuova Alpha, 1986), 213-235. See also, Ulisse Aldrovandi, Mostrorum Historia (Theatrum Sapientia), French edition (Paris: Belles Lettres, 2002); and Angela Lorenz, The Theater of nature, or, Curiosity filled the cabinet (Bologna; Novelties of Purpose, 2002).

${ }^{18}$ For the image, see the Pompeian wall of Polyphemus and Galatea MAN Naples 27687.jpg, Pompeii, House of the Ancient Hunt (VII, 4, 48), now in the Gabinetto Segreto in the National Archeological Museum in Naples. Also visible in the fresco is a ram, a shepherd's stick, and Pan's or Polyphemus's flute.

${ }_{19}$ See Enrico Maria Dal Pozzolo, Un apice erotico di Lavinia Fontana (Treviso: ZeL Edizioni, 2019), 45-70; for an careful analysis about depictions of female's buttocks from antiquity (Venus Callipyge) through the Cinquecento (Paolo Veronese); and Enrico Maria Dal Pozzolo, Lavinia’s Mars and Venus, cat. entry, in Ruiz Gómez, A Tale of Two Women Painters, 60-23.
} 


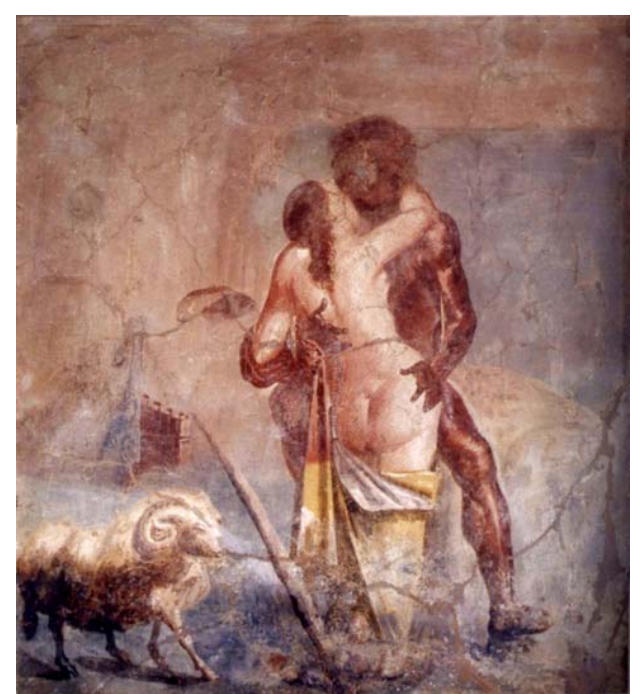

Figure 5. Galatea and Polyphemus, Roman fresco, House of the Ancient Hunt (VII, 4.48), Pompeii. National Archeological Museum, Naples. Photo credit: Commons.wikimedia.org.

In her conception of Galatea, Lavinia composed another paragone between classical beautiful and sensual women such as Venus and Galatea; similar examples can be seen in Cartari’s mythographic images of Venus and Galatea. ${ }^{20}$ In the Le imagini degli dei degli antichi, Cartari fused the images of Galatea and Fortuna in the design of Venus. In the Cartari's engraving, Venus too holds a wind-blown veil and rides on a propelled scalloped shell but dolphins and marine amorini conduct her navigation. One of the amorini blows vigorously into a conch announcing the transit of the goddess (Figure 6).

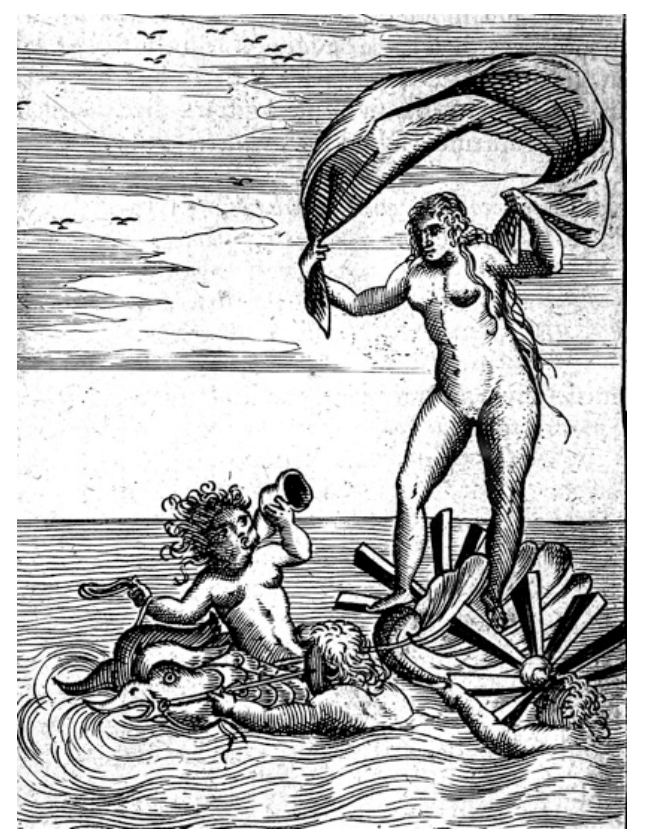

Figure 6. Vincenzo Cartari, Venus, in Le imagini degli dei degli antichi (Padua: Pietro Paulo Tozzi, 1608).

Photo credit: Internet Archive Book Images.

\footnotetext{
20 See Cartari, Le imagini dei degli antichi, 271, Venus. Paduan edition of Pietro Paulo Tozzi, 1600-1608.
} 
In Lavinia’s painting, Galatea's beautiful nude body, the décor of her attire, the amorini companions as cupids — in particular the ogling amorino — and her association with sexual appetites and lovemaking all indicate a close appropriation of physical and metaphysical associations between Galatea and Venus. Physically, their association is with exposed beautiful bodies and jewelry ornamentation. For example, Galatea's messy hairdo, with tresses filled with jewelry, alludes to the disruption of her attire caused by her unbalanced stance and unsteady navigation. Her gold armband inlaid with jewels signifies the traditional classical reference of belonging to a lover, a token similar to an engagement ring, while her elaborate jeweled gold strap assists in securing her transparent attire. Lavinia often dressed her mythological heroine with these favorite motifs, as seen in several of her paintings, including her Venus and Cupid of 1585 in a private collection in Venice, and the Portrait of Venus and Cupid or Isabella Ruini as Venus of 1592, at the Musée des Beaux-Arts in Rouen (inv. D 1874.15) (compare Figures 7 and 1). Metaphysically, the association is in connection with their amorous indiscretions: Venus with Mars; and Galatea with Acis. Moreover, the aquatic connections between the two include Venus's aquatic birth and Galatea's place of residence, the sea. In narrating these females' transit activities, artists, engravers, and mythographers often employed a scalloped shell or a sea monster as a riding artifact; for instance, compare the engravings of Cartari’s Galatea and Cartari's Venus, and Marcantonio Raimondi’s Venus with Lavinia’s Galatea (compare Figures 3, 6, 8, and 1). ${ }^{21}$

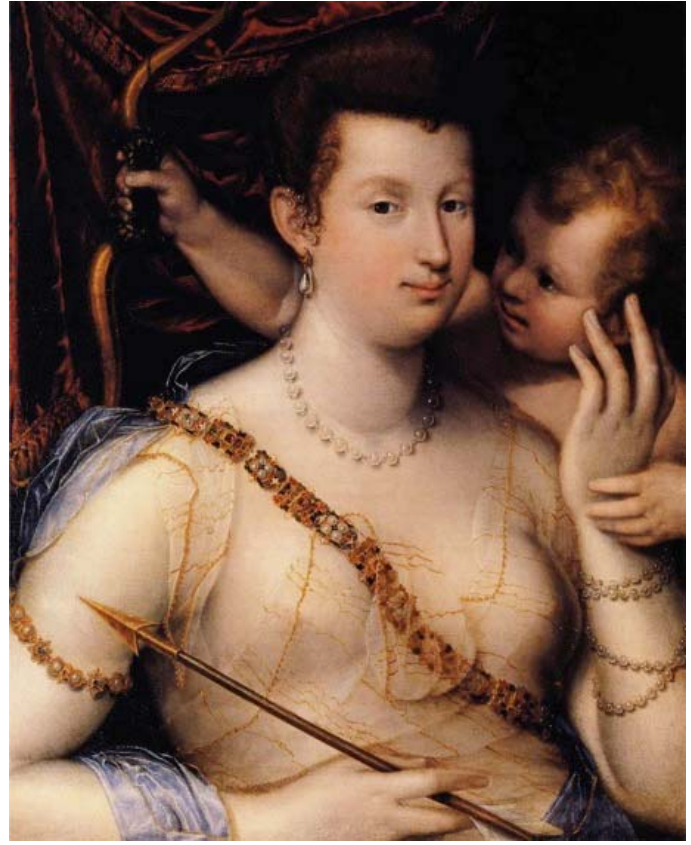

Figure 7. Portrait of Venus and Cupid or Isabella Ruini as Venus, 1592. Musée des Beaux-Arts de Rouen. Photo Credit: Courtesy of C. Lancien, C. Loisel /Réunion des Musées Métropolitains Rouen Normandie.

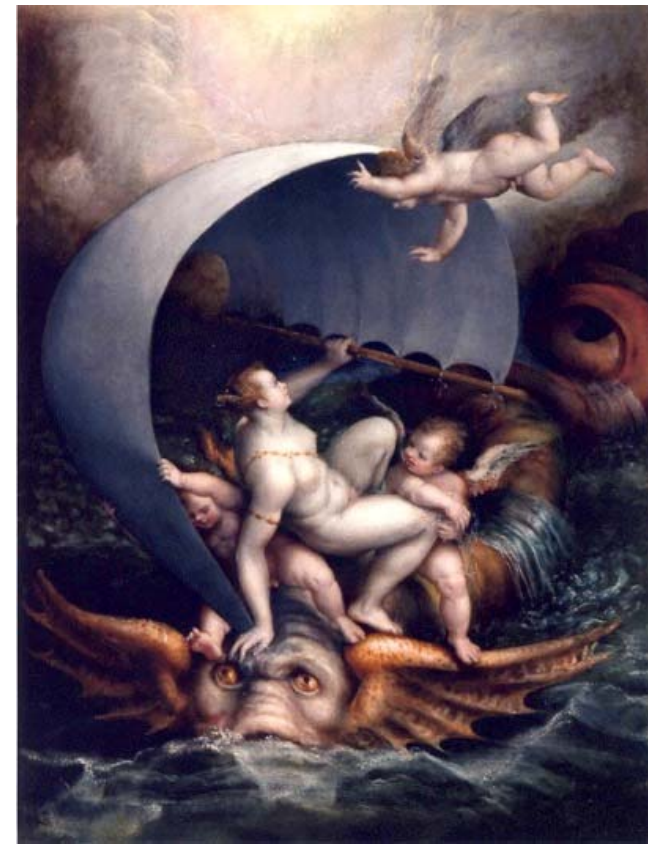

Figure 1. Lavinia Fontana, Galatea, 1590. Private collection in Bologna. Diletta Badescki. Photo credit: Courtesy of Prof. Fausto Gozzi and Mauro Lizzi, Editor, Zel.Edizioni.

\footnotetext{
${ }^{21}$ See Raimondi's engraving of Venus, 1520, from a sarcophagus of marine feasts in Palazzo Corsini in Rome. For the image, see https://www.artsy.net/artwork/marcantonio-raimondi-marcantonio-raimondi (accessed December 15, 2019); and Deborah Howard, “Venice as a Dolphin: Further Investigations into Jacopo de’ Barbari’s View,” Artibus et Historiae, 18.35 (1997): 101-111.
} 


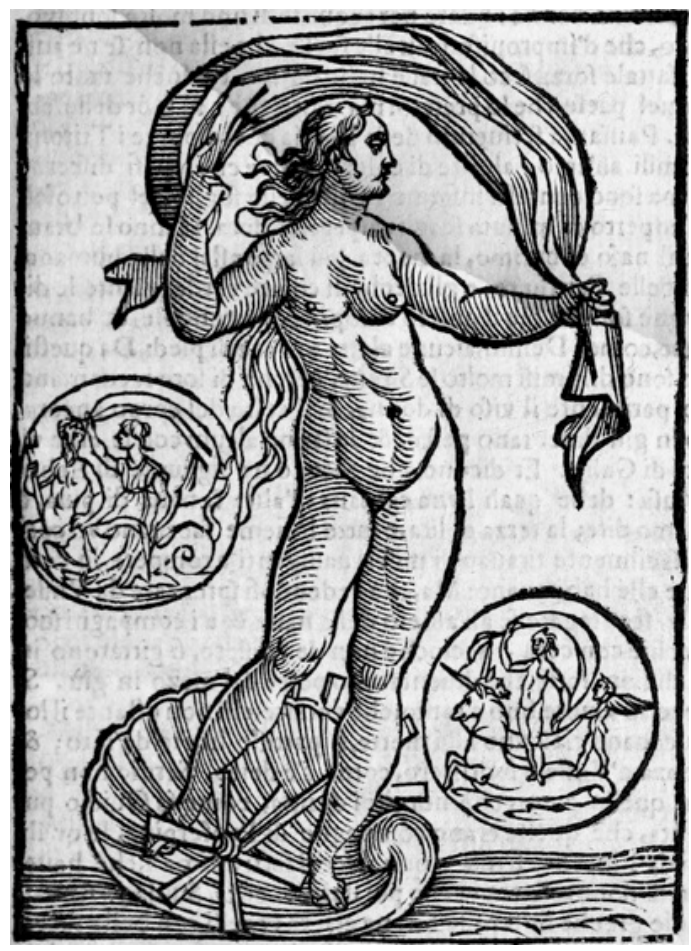

Figure 3. Vincenzo Cartari, Galatea, in Le imagini degli dei degli antichi (Venice: Francesco Marcolini, 1556, rep. 1647). Photo credit: Commons.wikimedia.org.

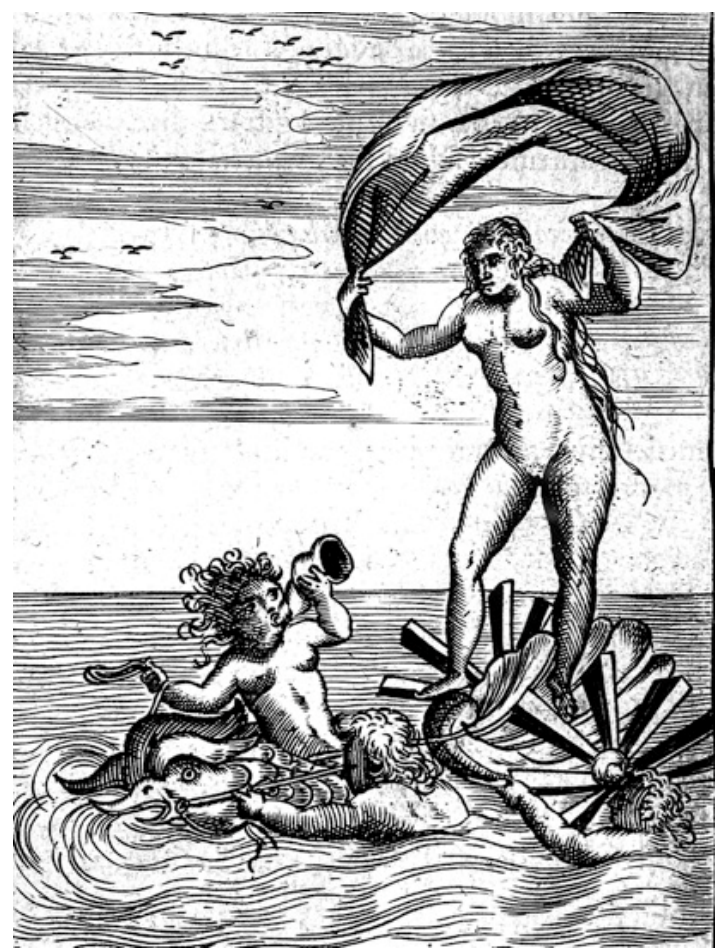

Figure 6. Vincenzo Cartari, Venus, in Le imagini degli dei degli antichi (Padua: Pietro Paulo Tozzi, 1608).

Photo credit:. Internet Archive Book Images.

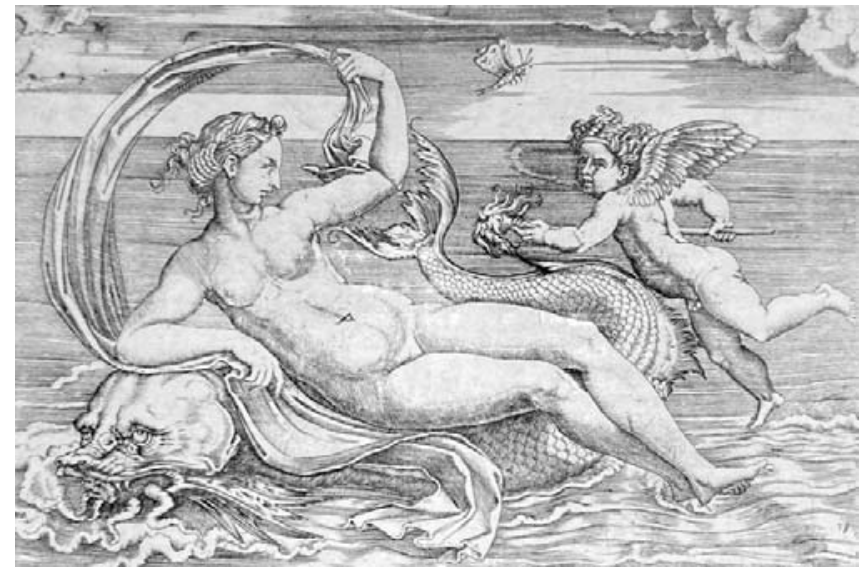

Figure 8. Marcantonio Raimondi, Venus, 1520s.

Engraving. Photo credit: Courtesy of Artsy.net.

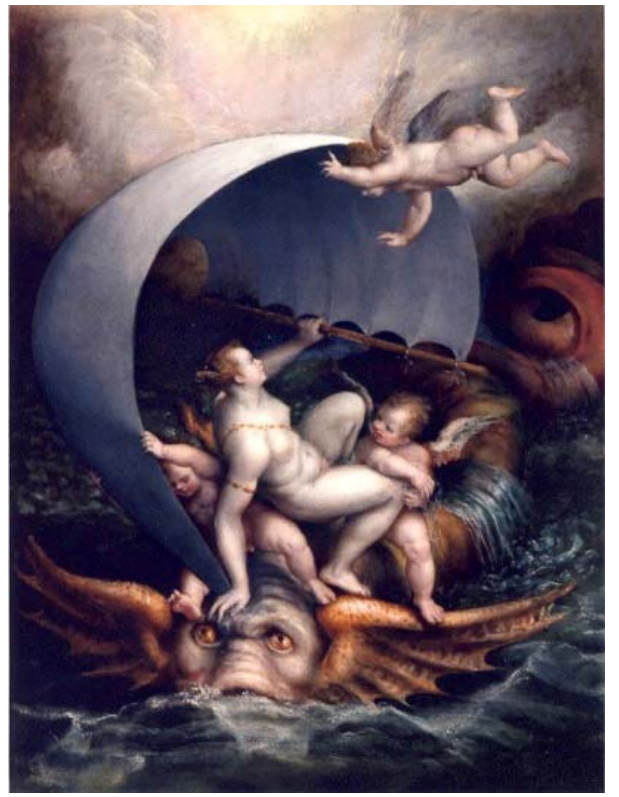

Figure 1. Lavinia Fontana, Galatea, 1590.

Private collection in Bologna. Diletta Badescki. Photo credit: Courtesy of Prof. Fausto Gozzi and Mauro Lizzi, Editor, Zel.Edizioni. 
In this work, Lavinia continued to tease and titillate the viewer. The décor of Galatea's transparent attire—an almost invisible veil—and the pose of her legs emphasize the erotic flavor of the painting. But has Lavinia added something else to this burlesque scene to seduce the viewer with delight? ${ }^{22}$

The Bolognese painter introduced many artistic innovations in her Galatea, challenging her artistic predecessors who portrayed this theme, such as Raphael in The Triumph Galatea of 1515 at the Villa Farnesina in Rome, and Giulio Romano in Polyphemus and Galatea of 1526 in the Sala di Psiche of the Palazzo del Te in Mantua (Figures 9 and 10); both seem to have followed the recounting of the saga according to Philostratus the Younger's Images (2:18):

The nymph sports on the peaceful sea, driving a team of four dolphins yoked together and working in harmony; and maiden daughters of Triton, Galatea's servants, guide them, curving them in if they try to do anything mischievous or contrary to the rein. She holds over her heads against the wind a light scarf of sea-purple to provide a shade for herself and a sail for her chariot, and from it a kind of radiance falls upon her forehead and her head, though no white more charming than the bloom on her cheek; her hair is not tossed by the breeze, for it is so moist that it is proof against the wind. And lo, her right elbow stands out and her white forearm is bent back, while she rests her fingers on her delicate shoulder, and her arms are gently rounded, and her breasts project, nor yet is beauty lacking in her thigh. Her foot, with the graceful part that ends in it, is painted as on the sea and it lightly touches the water as if it were the rudder guiding her chariot. Her eyes are wonderful, for they have a kind of distant look that travels as far as the sea extends. ${ }^{23}$

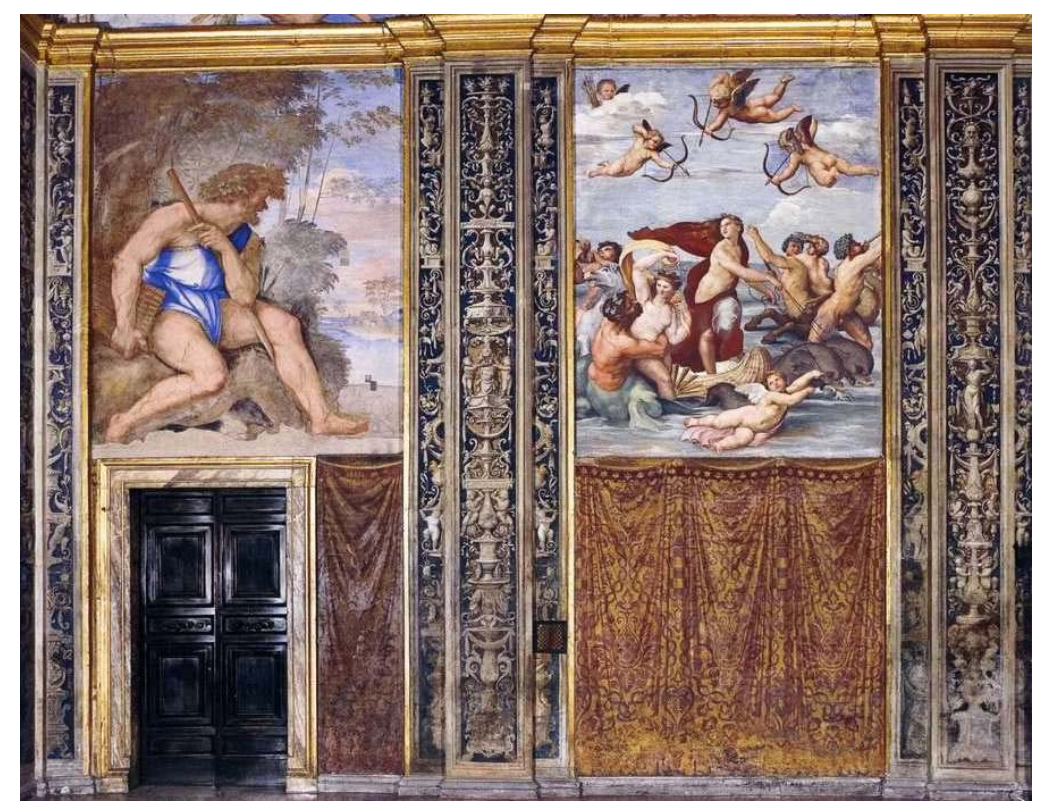

Figure 9. Raphael, Triumph of Galatea, 1515. Villa Farnesina, Rome. Photo credit: Commons.wikimedia.org.

\footnotetext{
${ }^{22}$ See David Cast, The Delight of Art: Giorgio Vasari and the Tradition of Humanist Discourse (University Park: Pennsylvania State University Press, 2011); and Paul Barolsky, Infinite Jest: Wit and Humor in Italian Renaissance Art (Columbia: University of Missouri Press, 1978).

${ }^{23}$ See Arthur Fairbanks, trans., Philostratus The Younger, Images (Cambridge, MA: Harvard University Press, Loeb 1931).
} 


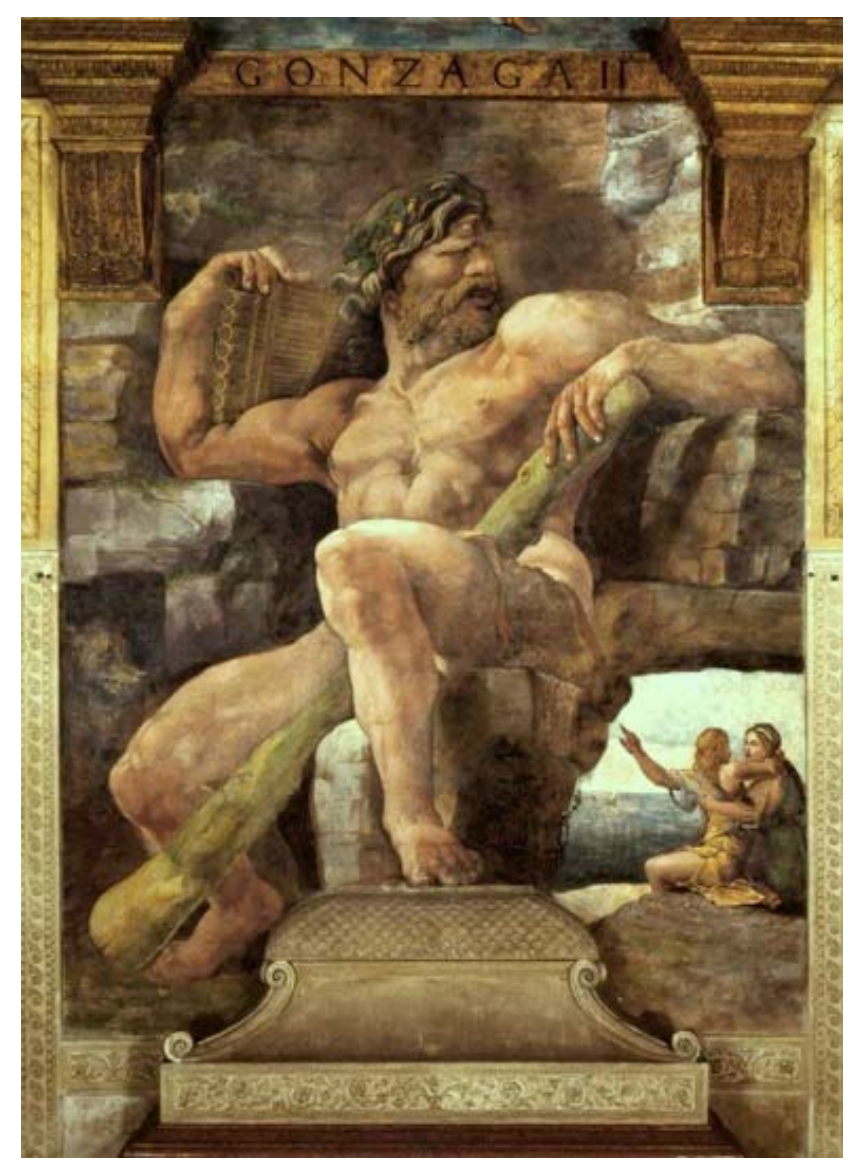

Figure 10. Giulio Romano, Polyphemus and Galatea, 1526. Sala di Psiche, Palazzo del Te, Mantua.

Photo credit: Commons.wikimedia.org, WGA09572.

Thematically, Lavinia selected Ovid's passages as a source. She focused on the gods' wrath and punishment of Galatea by causing a storm at sea while she was navigating. This action contrasts with the traditional depiction of Galatea with her dolphins and maidens peacefully and pleasantly parading and voyaging in calm waters. Conceptually, Lavinia added a humorous tone to the scene, perhaps absorbing Ovid's hidden comical meaning. She also infused her composition with erotic innuendoes. These undertones subtly direct the viewer towards an evaluation of proper demeanor in order to avoid a tragic calamity.

Lavinia appropriated and transformed some of her father Prospero's images, particularly those associated with nude females riding on a dolphin or sea monster on the ocean, as seen in the engraving of Acvmine, Ratione, Diligentia earier Qvivis Potest (Any man can achieve sharpness of the mind with his reason and with his intelligence), Symbol CVIII in Book IV of Achille Bocchi’s Symbolicae quaestiones, published in 1555 and reprinted in $1574 .{ }^{24}$ Prospero, along with his daughter Lavinia, had completed drawings for Bocchi's book, while the Bolognese Giulio Bonasone (1498-1576) engraved the drawings for this collection. ${ }^{25}$ In the treatment of the

\footnotetext{
24 See Gozzi, “Lavinia’s Galatea,” 214; and Vera Fortunati Pietrantonio, ed., Pittura Bolognese del '500, 2 vols. (Bologna: Grafis, 1986), 1:339-414, Entry on Prospero Fontana.

${ }^{25}$ See Stefania Massari, Giulio Bonasone, 2 vols. (Rome: Quasar, 1983); and Elizabeth Watson, Achille Bocchi and Emblem Books (Cambridge: Cambridge University Press, 2004).
} 
nude figure and the wind-blown sail, Lavinia was also inspired by her father's beautiful drawing of Virtue Subduing Fortune of 1553, in the Royal Collection Trust (RCIN 905990, Figure 11). ${ }^{26}$ She and her father were familiar with the established Genovese artist, Luca Cambiaso (1527-1585), who had travelled to and worked in Bologna and Rome. His sensual drawing of a Nymph and Putti Riding on a Dolphin dated 1580 is part of the Drawing Collection at the Fogg Museum of the Harvard Art Museums (OB1965-368, Figure 12), ${ }^{27}$ for example, shows affinities with Lavinia's Galatea. Cambiaso's humorous scene represents a nude figure, probably Galatea or Venus, holding on to a large wind-blown sail while standing on huge dolphin’s pectoral fin. With wide-open eyes and open mouth, the dolphin is drawn with an expression of disdain for having to carry such a heavy cargo. Three putti carrying dolphin calves ride along the side of this large dolphin attempting to assist Venus's navigation. The background of the drawing shows winged putti as personifications of Air and Wind in the sky and below them in the ocean are marine figures battling the waves in the rough sea. Galatea (Nymph) is impervious to them, struggling for her own stable navigation.

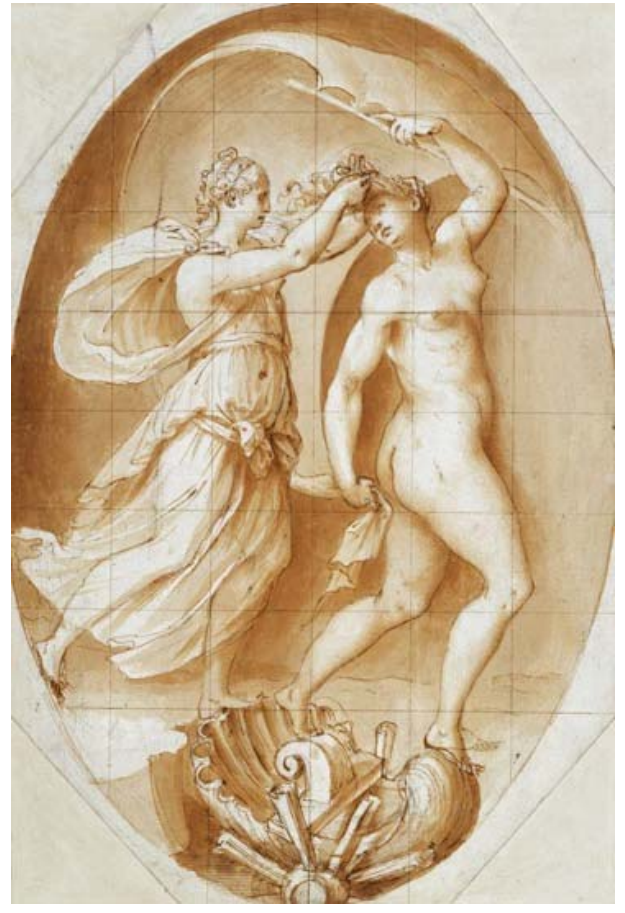

Figure 11. Prospero Fontana, Virtue subduing Fortune, 1553, pen ink drawing. Photo credit: Courtesy of the Royal Collection Trust / (C Her Majesty Queen Elizabeth II 2020.

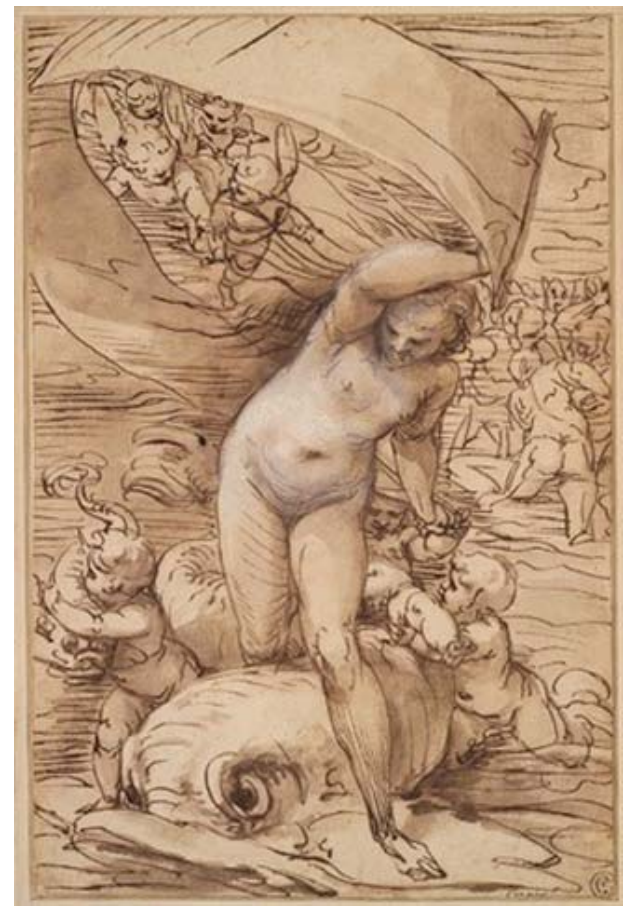

Figure 12. Luca Cambiaso, Nymph and Putti Riding on a Dolphin, 1580, drawing. Photo credit: Harvard Art Museums/Fogg Museum Bequest of Meta and Paul J. Sachs.

\footnotetext{
${ }^{26}$ See Lucy Whitaker and Martin Clayton, "Prospero Fontana," entry in the catalogue The Art of Italy in the Royal Collection: Renaissance and Baroque (London: The Royal Collection Trust, 2010), np. The drawing represented a conceit for the coat of arms of Pope Julius II. The design was to be included in the decoration of the pontiff's private residence, the Villa Giulia in Rome. For the image, see https://www.rct.uk/collection/905990/virtue-subduing-fortune (accessed December 15, 2019).

${ }^{27}$ See Edward J. Olszewski, “Drawings by Luca Cambiaso as a Late Renaissance Model of Invenzione,” Cleveland Studies in the History of Art, 5 (2000): 20-41.
} 


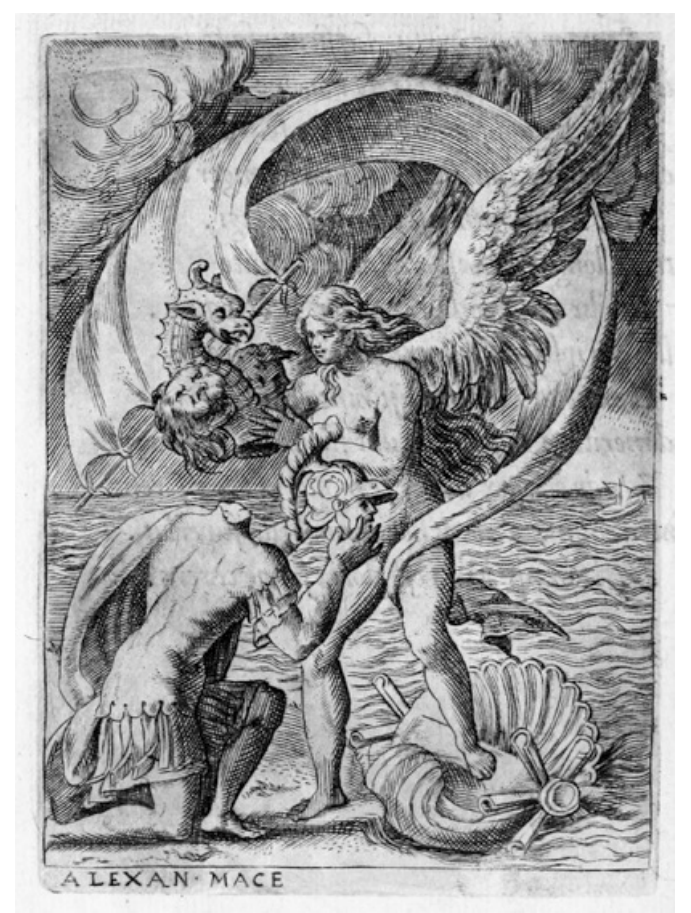

Figure 13. Achille Bocchi, Symbol LXVI, from Symbolicarum quaestionum (Bologna: Giulio Bonasone, 1574). Prospero Fontana and Lavinia Fontana illustrators. Photo credit: University of Glasgow Library, Archives \& Special Collections.

In contrast to the imagery seen in the drawings of Prospero and Cambiaso, Bocchi's engraving of Symbol LXVI, Bellva Fit Caecae Statvit quit Credere Sorti (He becomes a beast who has decided to trust blind fate) in Book III of Symbolicae quaestiones alludes thematically and visually to a sinister paragone (compare Figures 11 and 12 with 13). Bocchi's text reads:

Those whom she [Fortune] impelled to trust to her alone, blind Fortune for the most part makes greedier for honor than they have a right to: hence in olden times she ordered herself; not only the Macedonian youth born from great Jove suffered. When he desired to extend the fame of his deeds under her name, she destroyed him instead: That is what happens to one who continually entrusts himself to Fortune of his own accord. Truthfully in the realm of man she ruins him utterly, and he becomes a many-headed monster, deprived of light. ${ }^{28}$

The engraving represents a gruesome act on the part of Fortuna (similar to the cruelty of Polyphemus): ${ }^{29}$ she transforms the famous military leader Alexander the Great into a beast. In the engraving, Fortuna is winged, protected by her wind-blown sail, standing in front of the kneeling Alexander the Great. She steps out of her boat,

${ }^{28}$ See Peggy Muñoz Simonds, “To the Very Heart of Loss: Renaissance Iconography in Shakespeare’s Anthony and Cleopatra,” in Shakespeare Studies, vol. 22, ed. Leeds Barroll (London: Associated University Presses, 1994), 256-57. For the image, see achillisbocchiib01bocc_0190 (accessed December 15, 2019).

${ }_{29}$ The blindness of Polyphemus may explain his cruel nature and hostile. See Andrea Alciato's emblem on the imagery of the blinded cyclops Polyphemus. The emblem CLXXII, “Just Recompense” (Iusta vindicta), explains how Ulysses (the man from Ithaca), having been captured in the Cyclops’ cave escaped by blinding Polyphemus (Homer, Odyssey 9: 177-79). The text reads: "Sitting in the mouth of his arching cave, the Cyclops sang thus to himself amidst his gentle sheep: Do you feed on grass; I shall feed on the Greek companions, and last of all my belly shall get No-man. The man from Ithaca heard this and made the Cyclops eyeless. See how the one who plotted misfortune collects it himself!” See Andrea Alciato's Emblematum liber (Augsburg: Heinrich Steyner, 1531) and later edition Andrea Alciato’s Emblemata (Padua: Petro Paulo Tozzi, 1621). For the images, see https://www.emblems.arts.gla.ac.uk/alciato/books.php?id=A31a (accessed December 15, 2019). https://www.emblems.arts.gla.ac.uk/alciato/emblem.php?id=A21a172 (accessed December 15, 2019). 
a scalloped shell, severing his head, which is covered by a helmet. Cruelly, she replaces it with a tripartite-monster head composed of a lion, tiger, and eagle, while Alexander the Great diabolically holds his severed head in hands, exchanging it for Fortuna's cursed monster head. This emblem alludes to the foolishness of pride in the individual, Alexander (similar to that of vanity in Galatea), who succumbs quickly to bestial needs and Fortuna's tricks.

Curiously and paradoxically, in her Galatea, Lavinia depicted an erotic painting with a moralizing overtone with associations to Fortuna and Venus, fitting at once with Mannerism in style and the Counter-Reformation in meaning. Her sotto voce message recalls the sermons of her friend and spiritual mentor Cardinal Gabriele Paleotti in the Discorso intorno alle imagini sacre et profane, where he abhors the display of eroticism in mythological paintings but not in private settings. ${ }^{30}$ In her design of the perilous pose of Galatea-her hand and arm resting on the sea monster's forehead and the other hand holding onto a bar of the sail, as well as to the treatment of her bent legs-Lavinia is inspired by the depiction of falling-down figures in religious paintings, particularly in her treatment of arms, hands, and legs that support the body while the figure is about to lose its balance, as seen in the fallen figure of the disgraced Heliodorus running out of the temple in the fresco wall painting of the Expulsion of Heliodorus from the Temple of 1512 in the Apostolic Palace in Vatican City (Figure 14). ${ }^{31}$ Not by accident, years later, this pose of Heliodorus's was appropriated by the Mannerist painter Parmigianino for the figure of Saul thrown off his horse on the road of Damascus in The Conversion of Saint Paul of 1527, now at the Kunsthistorisches Museum in Vienna (Figure 15). ${ }^{32}$

\footnotetext{
${ }^{30}$ See Gabriele Paleotti, Discorso intorno alle immagine sacre e profane (Bologna: Alessandro Benacci, 1582), reprinted in Paola Barocchi, ed., Trattati d'arte fra manierismo e contrariforma (Bari: Laterza, 1960-1962), 117-509 (esp. 289-93); Ilria Bianchi, La politica delle immagine nell'età della Contrariforma. Gabriele Paleotti teoretico e committente (Bologna: Compositori, 2008), 219; Michele Danieli, "Pittura erotica tra Bologna e Praga: aggiunti a Denys Calvert e Dirck de Quade van Ravesteyn,” Czech and Slovak Journal of Humanities 3 (2016): 39-52; Caroline Murphy, Lavinia Fontana (New Haven, CT: Yale University Press, 2003), 8-12 and 184-85, for a discussion on Fontana and Paleotti; and Liana De Girolami Cheney, "Lavinia Fontana's Nude Minervas," Woman's Art Journal 36.2 (Fall/Winter 2015), 30-40, esp. 38.

31 The Bolognese engraver Marcantonio Raimondi (1488-1523) made a print of this scene, as well as most of Raphael's paintings, including The Judgment of Paris of 1520 at the Metropolitan Museum of Art in New York (Accession 2012.136.861), where in figure seated in the left-hand lower corner of the image is seen a similar pose. These engravings were probably familiar to Lavinia and her father Prospero, since Raimondi was a known Bolognese artist.

32 There are no Biblical or historical references noting that Saul fell from a horse. But in Acts 9:3-6, there is a description on Saul's journey to Damascus, where "he fell on the ground" (Acts 9:4). Renaissance painters have depicted Saul being thrown off a horse, since in 1515 Raphael's composed a cartoon about the event for the set of tapestries to be placed in the papal chapel or Sistine Chapel at the Vatican. See John White and John Shearman, "Raphael's Tapestries and Their Cartoons,” The Art Bulletin, 40.3 (September 1958):193-221; and Clare Brown and Mark Evans, eds. Raphael: Cartoons and Tapestries for the Sistine Chapel (London: Victoria and Albert Museum, 2011).
} 


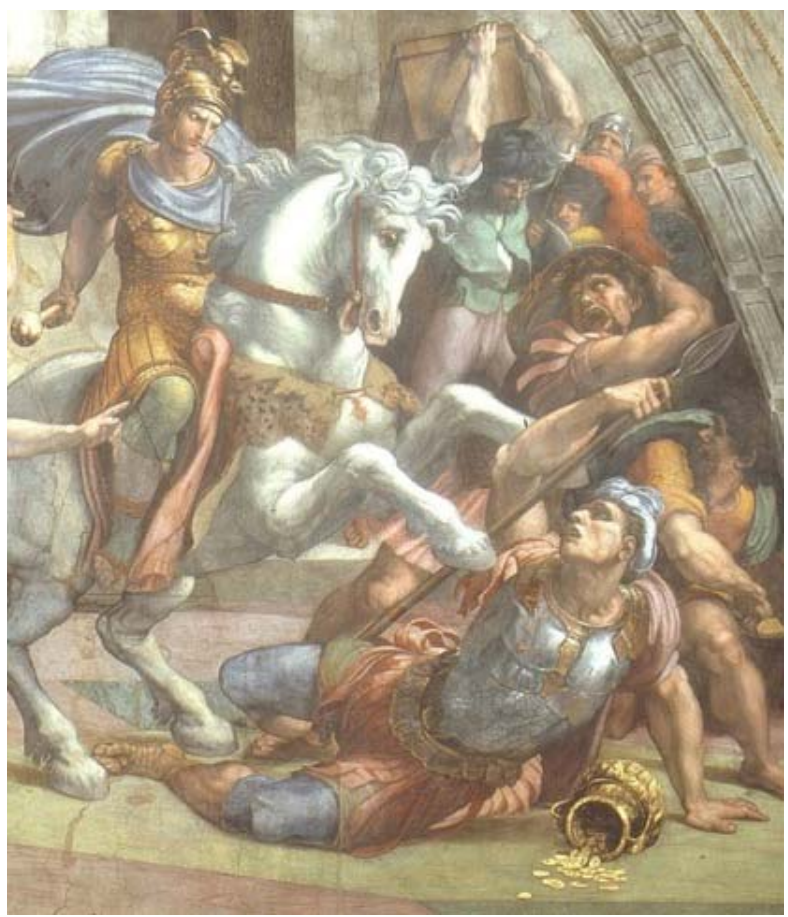

Figure 14. Raphael, Expulsion of Heliodorus from the Temple, det. 1512. The Apostolic Palace Vatican City. Photo credit: Commons.wikimedia.org.

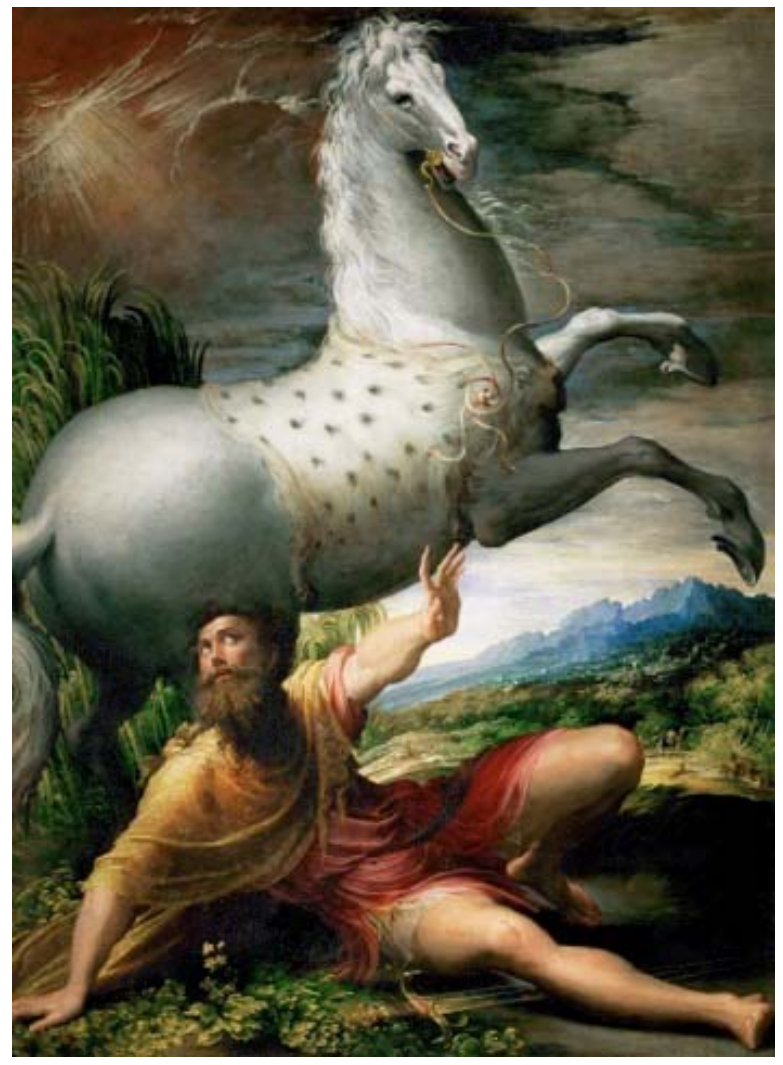

Figure 15. Parmigianino, The Conversion of Saint Paul, 1527. Kunsthistorisches Museum, Vienna. Photo credit: Commons.wikimedia.org 


\section{Conclusion}

In the signification of Galatea, Lavinia's moral conceit combines the power of natural forces represented by the pagan gods Jupiter (wind), Neptune (water), and Fortune (vicissitude of time) against the individual behavior of Acis, Galatea, and Polyphemus. She delineated the negative disposition of behavior toward the unnatural, such as Galatea's rejection of the ugly Polyphemus and the arrogant actions of pride and vanity in Galatea's seductive behavior, displaying her body and overtly expressed affection for Acis in order to torture Polyphemus. However, she added a positive note when inserting the amorino flying next to the wind-blown sail, as a divine messenger, with his index finger in a leadership gesture ${ }^{33}$ that points Galatea toward the heavens. ${ }^{34}$ Is he just pointing to the stormy heavens to guide her through her navigating maneuvers, or is he reminding her to repent for her coquettish actions and appease the fury of the celestial gods? Is Lavinia's Galatea just a recounting with humor of an ancient saga or is it also a moralizing tale?

\section{References}

Alciato, A. (1531). Emblematum liber. Augsburg: Heinrich Steyner.

Alciato, A. (1549). Los Emblemas. Lyons: Macé Bonhomme for Guillaume Rouille.

Alciato, A. (1621). Emblemata. Padua: Petro Paulo Tozzi,

Aldrovandi, U. (1642/2002). Mostrorum Historia (Theatrum Sapientia). Paris: Belles Lettres.

Barker, S. (2020). Exhibition Review: 'A Tale of Two Women Painters. Burlington Magazine https://www.academia.edu/41653667/Exhibition_Review_A_Tale_of_Two_Women_Painters.

Barocchi, P. (Ed.). (1960/1962). Trattati d'arte fra manierismo e contrariforma. Bari: Laterza.

Barolsky, P. (1978). Infinite Jest: Wit and humor in Italian renaissance art. Columbia: University of Missouri Press.

Benati, D. (2009). Un quadro grande con donne nude: da Joachim Wtewael a Lorenzo Sabatini. In D. Benati, (Ed.), Il più dolce lavorare che sia: mélanges enl'honneur de Mauro Natale. Milan: Silvana.

Bianchi, I. (2008). La politica delle immagine nell'età della Contrariforma. Gabriele Paleotti teoretico e committente. Bologna: Compositori.

Brown, C., \& Evans, M. (Eds.). (2011). Raphael: Cartoons and Tapestries for the Sistine Chapel. London: Victoria and Albert Museum.

Cartari, V. (1556/1571). Le imagini degli dei degli antichi. Venice: Francesco Marcolini.

Cartari, V. (1600-1608). Le imagini degli dei degli antichi. Padua: Pietro Paulo Tozzi.

Cast, D. (2011). The Delight of Art: Giorgio Vasari and the Tradition of Humanist Discourse. University Park: Pennsylvania State University Press.

Cheney, L. D. G. (2015). Lavinia Fontana’s Nude Minervas. Woman’s Art Journal, 36(2) (Fall/Winter), 30-40.

Costa, E. (1903). Andrea Alciato allo studio di Bologna. Bologna: Nicola Zanichelli.

Dal Pozzolo, E. M. (2009a). Un apice erotico di Lavinia Fontana. Treviso: ZeLEdizioni.

Dal Pozzolo, E. M. (2019b). Lavinia’s Mars and Venus. In L. R. Gómez (Ed.), A tale of two women painters: Sofonisba Anguissola and Lavinia Fontana. Madrid: Museo Nacional del Prado.

Daly, P. M. (Ed.). (1989). Andrea Alciato and the Emblem Tradition. Essays in Honor of Virginia Woods Callahan. New York: AMS Press.

Danieli, M. (2016). Pittura erotica tra Bologna e Praga: aggiunti a Denys Calvert e Dirck de Quade van Ravesteyn. Czech and Slovak Journal of Humanities, 3, 39-52.

Fairbanks, A. (Trans.). (1931). Philostratus the younger, images. Cambridge, MA: Harvard University Press, Loeb.

Fortunati Pietrantonio, V. (Ed.). (1986). Pittura Bolognese del ’500, (2 Vols). Bologna: Grafis.

\footnotetext{
33 See Jean Chevalier and Alain Gheerbrant, A Dictionary of Symbols (Oxford: Blackwell, 1994), 378, the index finger associated with the planetary correspondence of Jupiter as well as indicating the ability to address or to speak.

34 Gozzi, "Lavinia’s Galatea," 214, considers the painting a "theater of feelings," "a metaphor of a love triangle, and a moral interpretation of transformation expressed by the presence of the three cherubs."
} 
Gozzi, F. (2019). Catalogue and Cherubs riding the Stormy Waves on a Sea Monster. In L. R. Gómez (Ed.), A tale of two women painters: Sofonisba Anguissola and Lavinia Fontana. Madrid: Museo Nacional del Prado.

Hall, J. (1974/2014). Dictionary of subjects and symbols in art. New York: Harper \& Row, Publishers.

Hemming, A. (2008). The new technique of painting on copper. In M. Roth et al., Capture emotions: Baroque paintings in Bologna 1575-1725. Los Angeles, CA: J. Paul Getty.

Howard, D. (1997). Venice as a Dolphin: Further investigations into Jacopo de’ Barbari’s View. Artibus et Historiae, 18(35), 101-111.

Jay, P. (Ed.). (1973/1981). The Greek anthology and other ancient epigrams. Philadelphia, PA: Allen Lane.

Komanecky, M. (Ed.). (1988-1999). Copper as Canvas: Two centuries of Masterpiece painting on Copper, 1575-1775. Phoenix, AZ: Phoenix Art Museum.

Lorenz, A. (2002). The Theater of nature, or, curiosity filled the cabinet. Bologna; Novelties of Purpose.

Manning, H. (2002). The emblem. Edinburg: Reaktion Books.

Martin, C. (Trans.). (2005). Metamorphoses: New translation. New York: W. W. Norton \& Company.

Massari, S. (1983). Giulio Bonasone (2 Vols). Rome: Quasar.

Muñoz Simonds, P. (1994). To the Very Heart of Loss: Renaissance Iconography in Shakespeare’s Anthony and Cleopatra. In L. Barroll (Ed.), Shakespeare studies (Vol. 22). London: Associated University Presses.

Murphy, M. (2003). Lavinia Fontana. New Haven, CT: Yale University Press.

Olmi, G., \& Prodi, P. (1986). Gabriele Paelotti, Ulisse Aldrovandi, e la cultura a Bologna nel secondo Cinquecento. Nell'Eta di Correggio e dei Carracci: Pittura in Emilia dei Secoli XVI e XVII. Bologna: Nuova Alpha.

Olszewski, E. J. (2000). Drawings by Luca Cambiaso as a Late Renaissance model of invenzione. Cleveland Studies in the History of Art, 5 (2000), 20-41.

Paleotti, G. (1582). Discorso intorno alle immagine sacre e profane. Bologna: Alessandro Benacci.

Robinson, D. M. (1946). The wheel of fortune. Classical Philology, 41(4), 207-216.

Ruffini, M. (2009). A dragon for the pope: Politics and emblematics at the court of Gregory XIII. Memories of the American Academy in Rome, 54, 83-105.

Seznec, J. (1972). Survival of the Pagan Gods. Princeton, NJ: Princeton University Press.

Valeriano, G. P. (1556). Hieroglyphica. Basel: Michael Isengrin.

Watson, E. (2004). Achille Bocchi and emblem books. Cambridge: Cambridge University Press.

Whitaker, L., \& Clayton, M. (2010). Prospero Fontana. The art of Italy in the royal collection: Renaissance and Baroque. London: The Royal Collection Trust.

White, J., \& Shearman, J. (1958). Raphael’s tapestries and their cartoons. The Art Bulletin, 40(3), 193-221.

Wood, A. (2008). Of wing and wheels: A synthetic study of the Biblical Cherubim. Berlin: Walter de Gruyter. 